\title{
Basophil activation test versus radio-immunoassay in the diagnosis of $\beta$-lactam immediate-type hypersensitivity reactions
}

\section{Testul de activare a bazofilelor versus radio-imundozare în diagnosticul hipersensibilității de tip imediat la $\beta$-lactamine}

\author{
Cristina Petrişor ${ }^{1 *}$, Nadia Gherman-Ionică ${ }^{2}$, Ramona Bologa ${ }^{2}$, Manuela Sfichi ${ }^{3}$, \\ Natalia Hagău ${ }^{1}$
}

1. Department of Anaesthesia and Intensive Care, University of Medicine and Pharmacy "Iuliu Hatieganu" Cluj-Napoca, Romania

2. Department of Allergology and Immunology, University of Medicine and Pharmacy

"Iuliu Hatieganu” Cluj-Napoca, Romania

3. Department of Immunopathology, Clinical Emergency County Hospital Cluj, Romania

\begin{abstract}
Background and aims: to assess the sensitivity and specificity for the basophil activation test (BAT) and the detection of drug-specific antibodies $(\mathrm{IgE})$ in the retrospective diagnosis of $\beta$-lactam allergy by using assay-specific thresholds as resulted from the performance of receiver operating characteristics curve (ROC) analysis and to describe a sequential algorithm that might increase diagnostic sensitivity and reduce the number of patients that should undergo drug challenge tests by the joint use of in vivo and in vitro diagnostic tests. Methods: 37 patients with suspected $\beta$-lactam immediate-type hypersensitivity reactions were tested for the culprit drug. 31 healthy controls were similarly tested. BAT was performed with Flow2Cast technique (Bühlmann Laboratories, Switzerland). Drug-specific IgE antibodies were detected using "sandwich"-type radio-immunoassay (RIA) with sepharose as solid phase (Pathologie Université „H. Poincare”, France). Results: ROC curve analysis identifies an optimal threshold $>1.9$ for RIA positivity, with $70.3 \%$ sensitivity and $90.3 \%$ specificity. For BAT, an optimal threshold $>1.97$ yields $51.4 \%$ sensitivity and $90.3 \%$ specificity. $89.18 \%$ of the patients were diagnosed by the combined use of skin tests and in vitro tests results, while $10.82 \%$ of the patients had negative tests results. Conclusions: RIA seems to have higher sensitivity than BAT (70.3\% versus $51.4 \%)$ for $\beta$-lactams. The joint use of allergy diagnostic tests has $89.18 \%$ sensitivity. A combination of allergologic skin tests, detection of antibioticspecific antibodies, followed by BAT may be suitable for investigating $\beta$-lactam hypersensitivity reactions since no diagnostic test has absolute diagnostic accuracy.
\end{abstract}

Keywords: drug allergy, antibiotic, flow cytometry, basophil activation test

\section{Rezumat}

Premise şi obiective: evaluarea sensibilității şi specificității testului de activare a bazofilelor (BAT) şi a determinării anticorpilor specifici (IgE) în diagnosticul retrospectiv al hipersensibilității la $\beta$-lactamine folosind

*Corresponding author: Cristina Petrişor, Department of Anaesthesia and Intensive Care, Clinical Emergency County Hospital of Cluj, 400006 Clinicilor 3-5, Cluj-Napoca, Romania

Tel/Fax: +40 264599 438, e-mail: petrisor.cristina@umfcluj.ro 
criterii diagnostice stabilite prin efectuarea analizei curbelor ROC (receiver operating characterisitics curve) şi prezentarea unui algoritm diagnostic cu sensibilitate maximă care să reducă numărul de pacienți supuşi testelor de provocare. Metodă: 37 pacienți cu hipersensibilitate de tip imediat la $\beta$-lactamine au fost testați in vivo şi in vitro pentru antibioticul incriminat în istoric. 31 subiecți sănătoşi au fost testați similar. BAT a fost efectuat prin tehnica Flow2Cast (Bühlmann Laboratories, Switzerland). Determinarea anticorpilor IgE specifici a fost efectuată prin radio-imundozare “sandwich” (RIA) pe gel solid cu sefaroză (Pathologie Université „H. Poincare”, France). Rezultate: Analiza ROC defineşte un prag optim >1.9 pentru pozitivitatea RIA, cu sensibilitate de $70.3 \%$ şi specificitate de $90.3 \%$. Pentru BAT, un index optim>1.97 prezintă sensibilitate de $51.4 \%$ şi specificitate de 90.3\%. La $89.18 \%$ dintre pacienți diagnosticul a fost confirmat prin utilizarea combinată a testelor cutanate şi a celor in vitro, în timp ce $10.82 \%$ dintre pacienți au avut toate testele negative. Concluzii: RIA pare să aibă o sensibilitate superioară BAT (70.3\% versus $51.4 \%)$ pentru $\beta$-lactamine. Utilizarea simultană a testelor diagnostice alergologice prezintă sensibilitate de $89.18 \%$. Sumarea testelor cutanate cu detectarea anticorpilor specifici, urmate de BAT, este o secvență potrivită pentru diagnosticul reacțiilor de hipersensibilitate induse de $\beta$-lactamine, niciun test diagnostic prezentând acuratețe perfectă.

Cuvinte cheie: alergie medicamentoasă, antibiotic, citometrie de flux, test de activare a bazofilelor

Received: $31^{\text {st }}$ May 2013; Accepted: $21^{\text {st }}$ October 2013; Published: $2^{\text {nd }}$ December 2013.

\section{Introduction}

Allergy to $\beta$-lactam antibiotics is one of the most frequent causes of drug anaphylaxis, with $5 \%-10 \%$ of the population being allergic to B-lactams (1) and $29.4-47 \%$ of the patients with drug-induced hypersensitivity reactions having a $\beta$-lactam antibiotic as culprit drug $(2,3)$.

The retrospective diagnosis is mainly based on the clinical history, allergologic skin tests, and the detection of drug- specific $\operatorname{IgE}(3$, 4). Drug challenge, the gold standard diagnostic test, is time consuming and potentially dangerous. The quantification of basophil activation by flow cytometry (basophil activation test, BAT) has been considered a useful tool for the assessment of the immediate-type response to allergens mediated by IgE or by other mechanisms in drug allergic patients (5). BAT has not yet entered routine clinical practice, but more than $50 \%$ of the allergological centers use it in allergologic work-ups (6).

Being a potentially life-threatening condition, the retrospective diagnosis of $\beta$-lactam requires tests with high sensitivity, thus avoiding false negative results, for the detection of the culprit drug, as well as cross-reactivity. First, optimal allergen-specific thresholds for the determination of sensitivity and specificity are needed. The diagnostic accuracy of tests significantly improves by applying drug-specific cutoffs obtained from the receiver operating curves (ROC) analysis, which allows the comparison of different tests $(7,8)$. Second, studies to assess the equivalency of different diagnostic methods have rarely been performed.

Moreover, the joint use of both in vitro and in vivo studies might improve the sensitivity of the allergological surveys.

Objectives: to assess the sensitivity and specificity for the basophil activation test and the detection of drug-specific antibodies in the retrospective diagnosis of $\beta$-lactam allergy by using assay-specific thresholds as resulted from the performance of receiver operating characteristics curve (ROC) analysis and to describe a sequential algorithm that might increase diagnostic sensitivity and reduce the number of patients that should undergo drug challenge tests by the joint use of in vivo and in vitro diagnostic tests.

\section{Material and methods}

\section{Subjects}

The study was approved by the Research Ethics Committee of the University of Medicine and Pharmacy "Iuliu Hatieganu" 
Table 1. Antibiotic concentrations used in the allergologic skin tests and basophil activation test (BAT).

\begin{tabular}{|c|c|c|c|c|}
\hline Substance & SPT & IDT & BAT & Concentration \\
\hline & & & $\mathrm{c} 1$ & $1.25 \mathrm{mg} / \mathrm{mL}$ \\
\hline \multirow[t]{3}{*}{ Amoxicillin } & $25 \mathrm{mg} / \mathrm{mL}$ & $25 \mathrm{mg} / \mathrm{mL}$ & $\mathrm{c} 2$ & $0.125 \mathrm{mg} / \mathrm{mL}$ \\
\hline & & & $\mathrm{c} 3$ & $0.0125 \mathrm{mg} / \mathrm{mL}$ \\
\hline & & & $\mathrm{c} 1$ & $1.25 \mathrm{mg} / \mathrm{mL}$ \\
\hline \multirow[t]{3}{*}{ Ampicillin } & $25 \mathrm{mg} / \mathrm{mL}$ & $25 \mathrm{mg} / \mathrm{mL}$ & $\mathrm{c} 2$ & $0.125 \mathrm{mg} / \mathrm{mL}$ \\
\hline & & & $\mathrm{c} 3$ & $0.0125 \mathrm{mg} / \mathrm{mL}$ \\
\hline & & & $\mathrm{c} 1$ & $2 \mathrm{mg} / \mathrm{mL}$ \\
\hline \multirow[t]{3}{*}{ Penicillin G } & $25 \times 10^{3} \mathrm{UI} / \mathrm{mL}$ & $25 \times 10^{3} \mathrm{UI} / \mathrm{mL}$ & c2 & $0.2 \mathrm{mg} / \mathrm{mL}$ \\
\hline & & & c3 & $0.02 \mathrm{mg} / \mathrm{mL}$ \\
\hline & & & $\mathrm{c} 1$ & $2 \mathrm{mg} / \mathrm{mL}$ \\
\hline \multirow[t]{3}{*}{ Oxacillin } & $25 \mathrm{mg} / \mathrm{mL}$ & $25 \mathrm{mg} / \mathrm{mL}$ & c2 & $0.2 \mathrm{mg} / \mathrm{mL}$ \\
\hline & & & c3 & $0.02 \mathrm{mg} / \mathrm{mL}$ \\
\hline & & & $\mathrm{c} 1$ & $1.25 \mathrm{mg} / \mathrm{mL}$ \\
\hline \multirow[t]{3}{*}{ Ceftriaxone } & $2 \mathrm{mg} / \mathrm{mL}$ & $2 \mathrm{mg} / \mathrm{mL}$ & $\mathrm{c} 2$ & $0.125 \mathrm{mg} / \mathrm{mL}$ \\
\hline & & & c3 & $0.0125 \mathrm{mg} / \mathrm{mL}$ \\
\hline & & & $\mathrm{c} 1$ & $1.25 \mathrm{mg} / \mathrm{mL}$ \\
\hline \multirow[t]{2}{*}{ Cefuroxime } & $2 \mathrm{mg} / \mathrm{mL}$ & $2 \mathrm{mg} / \mathrm{mL}$ & $\mathrm{c} 2$ & $0.125 \mathrm{mg} / \mathrm{mL}$ \\
\hline & & & c3 & $0.0125 \mathrm{mg} / \mathrm{mL}$ \\
\hline
\end{tabular}

SPT $=$ skin prick test; IDT $=$ intradermal test; $\mathrm{BAT}=$ basophil activation test.

Cluj-Napoca. After signing the informed consent form, 37 adult patients with a positive history of an immediate-type hypersensitivity reaction to $\beta$-lactam antibiotics were tested for the culprit drugs. 31 healthy controls without previous drug allergies were also tested in vivo and in vitro to different $\beta$-lactam antibiotics they tolerated well. Exclusion criteria were therapy with steroid medication or $\mathrm{H}_{1}$ or $\mathrm{H}_{2}$ antihistamines in both patients and controls.

\section{In vivo tests}

The allergological skin tests included the skin prick test (SPT) and the intradermal test (IDT). Each was performed using solutions of antibiotics for parenteral use (Table 1). The skin tests were performed according to international recommendations (9).

\section{tivation test $(B A T)$}

In vitro flow cytometry- Basophil ac-

For BAT, flow cytometric analysis of in vitro activated basophils was performed with
Flow2Cast technique (Bühlmann Laboratories AG, Switzerland), as we described in a previous article (10). We used 6 test tubes containing $50 \mu 1$ of whole blood. The blood was collected into KEDTA venipuncture tubes, up to the dedicated volume, from antecubital vein (no garrot). We performed the cell stimulation immediately after collection of the blood and we did not store the blood samples. The first sample was mixed with $50 \mu \mathrm{l}$ of stimulation buffer as negative control. The next two samples were mixed with $50 \mu \mathrm{l}$ solution of anti-FceRI (a highly specific monoclonal antibody for the $\operatorname{IgE}$ receptor) and $50 \mu 1$ solution of FMLP (an unspecific cell activator- the chemotactic peptide N-Formyl- Met-Leu), as positive controls. In the remaining 3 test tubes, $50 \mu \mathrm{l}$ of antibiotic solution was added. The tested drug concentrations were $\mathrm{c} 1, \mathrm{c} 2$ and $\mathrm{c} 3$ for each drug, as presented in Table 1. Subsequently, $20 \mu \mathrm{l}$ staining reagent with two monoclonal antibodies, antiCCR3-PE (human chemokine receptor labelled 
with phycoerythrin) and anti-CD63-FITC (or Gp53, a glycoprotein expressed on activated basophils), were added in each tube. The samples were incubated for $15 \mathrm{~min}$ at $37^{\circ} \mathrm{C}$ in a water bath. A prewarmed lysing solution of $2 \mathrm{ml}$ was added to each tube and incubated for 10 minutes at room temperature. After centrifuging (500xg, 5 minutes) and washing, the cells were suspended in $300 \mu 1$ wash buffer. The up-regulation of CD63 marker on the basophils was measured using Cell Quest programme (FACSCalibur Becton Dickinson San Jose California USA Analyzer 2001). Our flow cytometer is equipped to detect forward scatter, side scatter and the two fluorochromes FITC and PE. Our laboratory limit of basophilic cells analyzed for allergies was set to 500 . The gate was set by including the entire basophil population CCR3 with low side scatter (SSC low) and calculating the percentage of CD63 positive cells compared to the total amount of basophilic cell gated. The result was expressed as the stimulation index (SI), which is calculated as the percentage of activated basophils after stimulation with antibiotic divided by the number of basophils with no stimulation.

In vitro radio-immunoassay (RIA)the detection of drug-specific antibodies $(R)$

We detected drug-specific IgE antibodies (IgE) using "sandwich"-type RIA with sepharose as solid phase (Pathologie Cellulaire et Moléculaire en Nutrition, Université „H. Poincare”, Nancy, France) and anti-IgEs I ${ }^{125}$-labelled antibodies (Immunotech, Czech Republic). 50 $\mu 1$ patient serum were incubated while centrifuging with the culprit antibiotic fixed in the sepharose gel for 3 hours at $24^{\circ} \mathrm{C}$. After washing for three times with phosphate buffer solution, 50 $\mu 1$ solution with anti-IgEs I ${ }^{125}$-labelled antibodies were added and the samples were incubated for 18 hours. Radioactivity was determined with LKB gamma-counter (CliniGamma 1272-003, Wallac Oy, Finland). The final result was expressed as R, the ratio between the percentage of antibody fixed when using patient serum and the percentage of fixed antibody when using serum from healthy controls.

\section{Statistical analysis}

The stimulation indexes for BAT (SI) and the presence of drug-specific antibodies by using radioimmune assay $(\mathrm{R})$ for all subjects and all concentrations were analysed. Receiver operating characteristics curve (ROC) analysis was performed with the highest SI and R as discrimination variables. The reference standard was considered when patients had positive history of allergy to $\beta$-lactam antibiotics. The area under curve (AUC), sensitivity and specificity were evaluated $(11,12)$. U Mann-Whitney test was used to establish the presence of significant statistical differences between mean values for numerical data. A $p<0.05$ was considered significant.

\section{Results}

A total of 37 adult patients (31 female and 6 male patients) with positive history of $\beta$ lactam antibiotics immediate-type hypersensitivity reactions were tested in vivo and in vitro for the culprit $\beta$-lactam antibiotics (amoxicillin, ampicillin, oxacillin, ceftriaxone or penicillin). From the 37 patients, 17 presented positive skin tests for the culprit drug (either skin prick test or intradermal test), while 20 patients had negative skin tests. Immediate-type hypersensitivity symptoms ranged from urticaria (12 patients) and angioedema (9 patients) to severe bronchospasm (4 patients), hypotension (3 patients) and shock (9 patients) (Supplemental material 1). 31 healthy controls with no previous $\beta$-lactam allergic reactions and negative skin tests were similarly tested in vivo and in vitro.

When detecting drug-specific IgE, patients had a mean R value of 2.39 (95\% CI 1.872.91, range 1-10.7), while controls presented a mean $\mathrm{R}$ value of 1.61 (95\% CI 1.50-1.72, range 1-2.20), with patients having significantly higher values than controls (U Mann-Whitney test p <0.001) (Figure 1). Flow cytometry revealed SI mean values of 2.33 (95\%CI 1.633.03, range 0.35-12.41) for the patients and 1.44 (95\% CI 1.23-1.66, range 0.51-3.41) for con- 


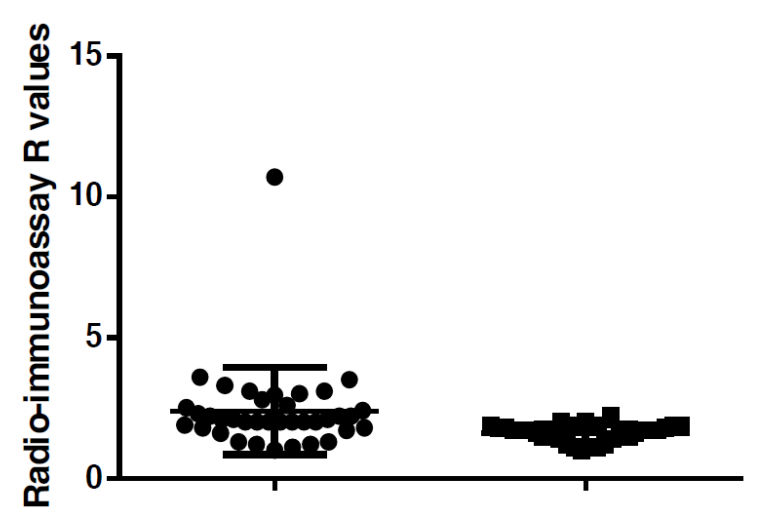

\section{Group A (patients) Group B (controls)}

Figure 1. Radio-immunoassay $R$ values for group $A$ (patients) and group $B$ (controls).

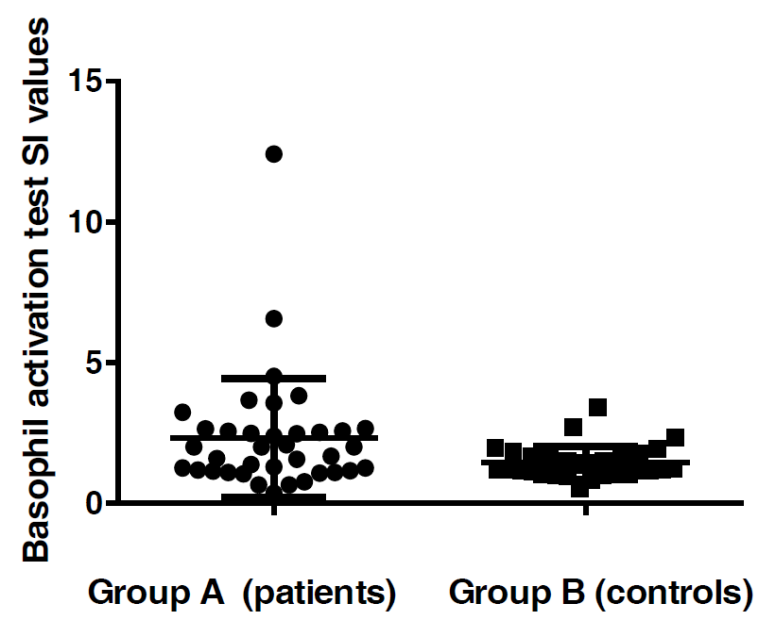

Figure 2. Box-plot for SI values (stimulation index) for basophil activation test for group A (patients) and group B (controls).

trols, the two results being significantly different (U Mann-Whitney test p<0.05) (Figure 2).

For radio-immunoassays, ROC curve analysis identified and optimal threshold of 1.9 for R, with an area under curve of 0.79 (95\%, CI 0.67-0.88). With this specific threshold the detection of drug-specific antibodies has $70.3 \%$ sensitivity and $90.3 \%$ specificity.

For flow cytometry, by performing the ROC curve analysis we found a SI>1.97 as the optimal threshold for BAT positivity. For BAT, an area under curve of 0.65 (95\% CI 0.53-0.76), with $51.4 \%$ sensitivity and $90.3 \%$ specificity were obtained using a cut off 1.97 . These values seem lower than those found for R, but there is no significant statistical difference between the ROC curve performed for R and SI ( $\mathrm{p}=0.11$ ) (Figure 3).

From the 20 patients with negative skin tests 13 present positive RIA results. From these, 3 also present positive BAT, while 10 are BAT negative. The remaining 7 patients with negative skin tests and negative RIA result present either positive BAT ( 3 patients) or negative BAT (4 patients).

Using allergologic skin tests, 17 out of 37 patients with previous $\beta$-lactam allergy are identified $(45.94 \%)$. By adding the detection of drug-specific antibodies from the 20 patients with negative skin tests, 13 are detected as being positive (17 skin tests positive plus 13 positive IgE_R, 30 out of the 37 patients $=81.08 \%$ ). By adding the performance of flow cytometry, 3 extra patients are identified as being positive (33 out of the 37 patients $=89.18 \%$ ). Thus, from the 37 patients, 4 present negative in vivo and in vitro diagnostic tests $(10.82 \%)$. From the 20 patients with negative skin tests, 13 are identified as having drug specific antibodies (positive RIA result) and 3 are identified as being BAT positive. The combined use of in vitro tests in patients with negative skin tests and positive history confirms the diagnosis of $\beta$-lactam allergy in $80 \%$ patients ( 16 out of 20 patients).

\section{Discussion}

The retrospective diagnosis of a $\beta$-lactam induced immediate-type hypersensitivity reaction includes positive history and both allergologic skin tests and in vitro tests in order to confirm the allergic reaction caused by the culprit drug and to identify cross-reactive compounds.

Skin tests are currently the reference tests for the diagnosis of antibiotic allergy, though their diagnostic value is not absolute. Their specificity for $\beta$-lactams is $97-99 \%$, whereas the sensitivity is 


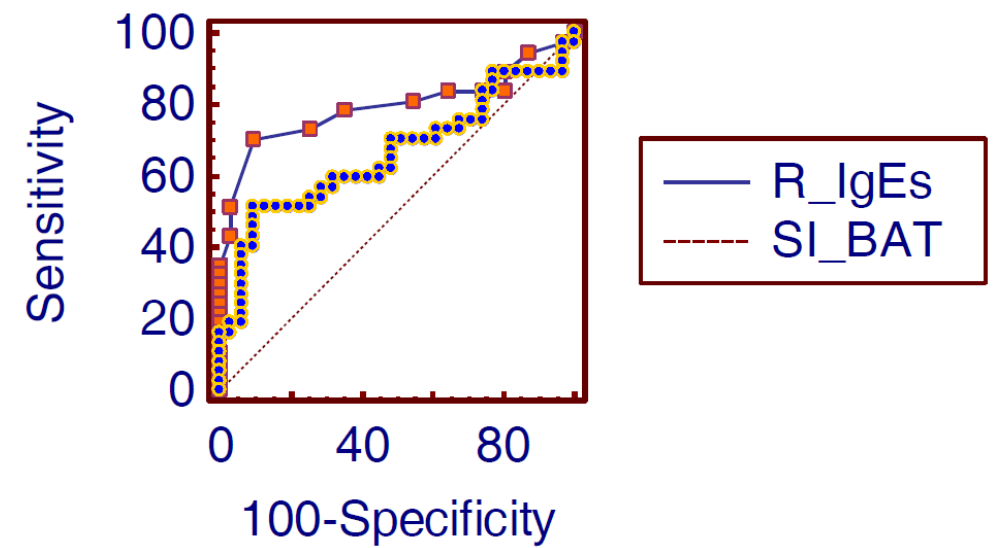

Figure 3. Receiver operating characteristics (ROC) curves for in vitro techniques: radio-immunoassay $(R)$ and flow cytometry (BAT). represent the maximal cellular response after optimal stimulation (maximal cellular reactivity).

None of the available diagnostic tests demonstrates absolute accuracy. A false-negative diagnosis might put the patients at risk for inducing anaphylaxis upon reexposure to the culprit drug. Most of the in vitro allergy tests have shown good specificity for drugs, but the low sensitivity still remains a major drawback. The assessment of sensitivity needs specific thresholds to be used for the diagnosis. These can be found by performing ROC curve analysis to establish optimal sensitivity and specificity.

In our study, the ROC curve analysis idenover time, a phenomenon particularly relevant for antibiotics (14), thus false negative results might occur. Skin tests are negative in a variable, but significant percentage of patients allergic to betalactams, ranging from $10 \%$ to $36 \%$ (15). Therefore, challenge tests in patients with suggestive clinical history and negative skin test is recommended. Challenge tests carry the risk of inducing potentially dangerous allergic reaction and may even present false negative results when the time frame between the allergic reaction and testing is large, the performance of retests being sometimes required. Thus, reliable in vitro tests are necessary.

The identification of $\mathrm{IgE}$ antibodies can be performed by using either ELISA or radio-immunoassay (RIA) techniques. Serum specific IgE assays are still the most common in vitro methods for evaluating immediate reactions (16). Studies in patients with allergic reactions to penicillins indicate that RIA has a sensitivity of around $50 \%$, and a specificity of $95 \%(17,18)$.

Flow cytometry (BAT) is at the present time a widely confirmed and clinically validated test (19), with sensitivity about $50 \%$ and specificity about $90 \%$ (7). BAT represents a suitable complement to the in vitro and in vivo tests used to quantify $\operatorname{IgE}(17)$. We chose to analyze the highest stimulation index in BAT as this might tified an optimal threshold $>1.9$ for RIA positivity, with $70.3 \%$ sensitivity and $90.3 \%$ specificity. For BAT, an optimal threshold $>1.97$ yields $51.4 \%$ sensitivity and $90.3 \%$ specificity. A SI>2 as optimal threshold for BAT positivity for antibiotics has been previously described in large multicenter studies, with $50 \%$ sensitivity $(1,20,21)$. By comparing the ROC curves performed for R and SI, the area under curve and the sensitivity seems to be lower for BAT when compared to RIA, but the statistical significant difference has not been attained $(\mathrm{p}=0.11)$. A larger number of cases would be needed to assess the difference between the two in vitro techniques used in the evaluation of $\beta$-lactam hypersensitivity. For drugs the lower observed sensitivity of the test probably reflects a weaker allergenicity of these molecules (22). The low sensitivity can also be explained by the time-dependent decrease in reactivity of the cells involved in allergic reactions. A loss of sensitivity that occurs naturally and gradually year by year when the culprit drugs are avoided in allergic patients has been described and explains the occurrence of negative diagnostic tests in allergic patients $(2,17,23,24)$.

Skin tests, determination of drug-specific antibodies and flow cytometry do not always show concordance between their results, as is the 
case in our study. Both RIA and BAT revealed significantly higher values for patients compared to controls. Thus, both in vitro techniques discriminate well between patients and controls. They may be used as complementary in oder to increase the allergologic survey sensitivity.

Being a potentially life threatening condition, the retrospective diagnosis of antibiotic-induced hypersensitivity reactions might benefit from the joint use of allergologic skin tests and in vitro tests. A diagnostic approach using skin tests, $\operatorname{IgE}$ dosing and drug challenge is necessary in the diagnosis of $\beta$-lactam allergy since none has sufficient sensitivity to be used alone (25). BAT has a similar sensitivity to immunoassays, but the combination of both tests improves sensitivity (20). The performance of BAT in patients with negative skin tests and negative $\operatorname{IgE}$ results might avoid potentially dangerous challenge tests. The combination of the BAT with the other tests increases the sensitivity of allergologic workups, reducing the need for drug provocation tests (26).

The combined use of skin tests, RIA and BAT has $89.18 \%$ sensitivity and limits the need for the performance of drug challenge tests to $10.8 \%$ of the patients. Negative diagnostic tests do not definitely exclude hypersensitivity and these patients have to perform drug challenge tests to confirm or rule out $\beta$-lactam hypersensitivity.

Allergologic skin tests and afterwards the detection of antibiotic-specific antibodies, followed by BAT may be a suitable practical approach when previous tests are negative in patients with previous immediate-type hypersensitivity reactions induced by antibiotics. In patients with severe reactions, the in vitro test should be the first choice in the diagnostic evaluation $(27,28)$.

\section{Conclusions}

ROC curve analysis identifies an optimal threshold $>1.9$ for RIA positivity, with $70.3 \%$ sensitivity and $90.3 \%$ specificity. For BAT, an optimal threshold $>1.97$ yields $51.4 \%$ sensitivity and $90.3 \%$ specificity. RIA seems to have higher sen- sitivity when compared to flow cytometry for $\beta$ lactam antibiotics immediate-type hypersensitivity reactions. The combined use of allergy diagnostic tests has $89.18 \%$ sensitivity and limits the need for the performance of drug challenge tests to $10.8 \%$ of the patients. Allergologic skin tests and afterwards the detection of antibiotic-specific antibodies, followed by BAT may be a suitable practical approach when previous tests are negative in patients with positive history suggestive of an immediate-type hypersensitivity reaction.

Acknowledgements. The study was performed with the financial support from the National Plan II, Priority Domain Partnership (research project 41-062/14.09.2007, Romania).

Conflict of interest disclosure. None of the authors has any conflicts of interest to declare.

Supplemental material is available in the electronic version of this article, on the journal's website: www.rrml.ro.

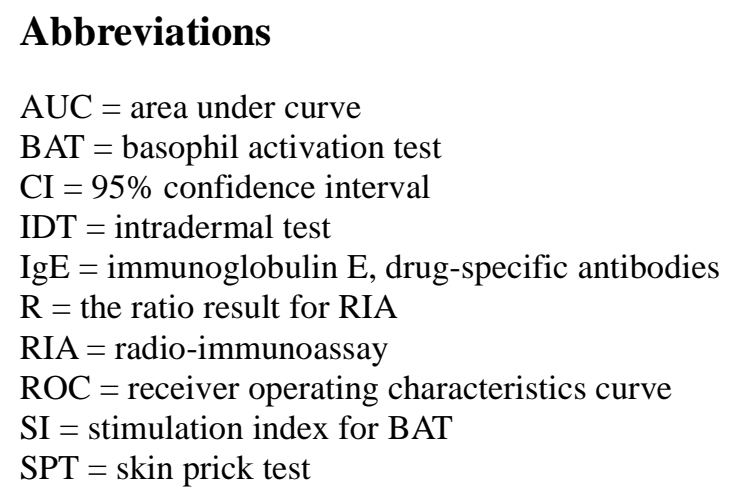

\section{References}

1. De Weck AL, Sanz ML, Gamboa PM, Aberer W, Sturm G, Bilo MB, et al. Diagnosis of immediate-type Blactam allergy in vitro by flow-cytometric basophil activation test and sulfi doleukotriene production: a multicenter study. J Investig Allergol Clin Immunol 2009; 19: 91-109.

2. Dona I, Blanca-Lopez N, Torres M, Garcia-Campos J, Garcia-Nunez I, Gomez F, et al. Drug Hypersensitivity Reactions: Response patterns, Drug Involved, and Temporal Variations in a Large Series of Patients. J Investig Allergol Clin Immunol 2012; 22(5):363-371.

3. Garcia Nunez I, Barasona Villarajo M, Algaba Marmol M, Moreno Aguilar C, Guerra Pasadas F. Diagnosis of 
Patients with Immediate Hypersensitivity to $\beta$-Lactams Using Retest. J Investig Allergol Clin Immunol 2012;22(1):41-7.

4. Boumiza R, Debard A, Monneret G. The basophil activation test by flow cytometry: recent developents in clinical studies, standardisation and emerging perspectives. Clin Mol Allergy 2005; 3:9.

5. Sanz ML, Gamboa PM, De Weck AL. Cellular Tests in the Diagnosis of Drug Hypersensitivity. Current Pharmaceutical Design 2008; 14: 2803-2808.

6. Thong BY, Mirakian R, Castells M, Pichler W, Romano A, Bonadonna $\mathrm{P}$, et al. A world allergy organization international survey on diagnostic procedures and therapies in drug allergy/hypersensitivity. World Allergy Organ J. 2011;4(12):257-70.

7. Ebo DG, Leysen J, Mayorga C, Rozieres A, Knol E, Terreehorst I. The in vitro diagnosis of drug allergy: status and perspectives. Allergy 2011; 66:1275-1286.

8. Ebo DG, Hagendorns MM, Bridts C, Scherwegh A, De Clerck L, Stevens W. In vitro allergy diagnosis: should we follow the flow? Clin Exp Allergy 2004; 34: 332-339.

9. Demoly P, Piette V, Bousquet J. In vivo methods for study of allergy: skin tests, technique and interpretation. In: Adkinson NF Jr, Yunginger JW, Busse WW, Bochner BS, Holgate TS, Simons FER, editors. Middleton's Allergy, principles and practice, 6th ed. Philadelphia, Pennsylvania: Mosby, Inc. 2003; 631-643.

10. Natalia Hagău, Manuela Sfichi, Ramona Bologa, Simona Cocu, Cristina Indrei, Ionel Alb, et al. Basophil activation test using flow cytometry in the diagnostic of antibiotic allergy. Rev Romana Med Lab. 2010;18(4):4753.

11. Bamber D. The area above the ordinal dominance graph and the area below the receiver operating characteristics graph. Journal of Mathematical Psychology 1975;12: 387-415.

12. Hanley JA, McNeil BJ. The meaning and use of the area under a receiver operating characteristic (ROC) curve. Radiology 1982;143: 29-36.

13. Mertes PM, Tajima K, Regnier-Kimmoun MA, Lambert M, Iohom G, Gueant-Rodriguez R, et al. Perioperative anaphylaxis. Med Clin N Am 2010; 94:761-789.

14. Ebo DG, Fisher MM, Hagendorens MM, Bridts CH, Stevens WJ. Anaphylaxis during anaesthesia: diagnostic approach. Allergy 2007: 62: 471-487.

15. Gamboa PM, Garcia-Aviles MC, Urrutia I, Antepara I, Esparza, Sanz ML. Basophil activation and sulfidoleukotriene production in patients with immediate allergy to betalactam antibiotics and negative skin tests. J Invest Allergol Clin Immunol 2004; 14: 278-283.

16. Romano A, Torres M, Castells M, Sanz M, Blanca M. Diagnosis and management of drug hypersensitivity reactions. J Allergy Clin Immunol 2011; 127(3):S67-S73.
17. Mayorga C, Sanz ML, Gamboa PM, Garcia B. In vitro diagnosis of immediate allergic reactions to drugs: An update. J Investig Allergol Clin Immunol 2010;20(2):103-109.

18. Fontaine C, Mayorga C, Bousquet PJ, Arnoux B, Torres M, Blanca M, et al. Relevance of the determination of serum-specific IgE antibodies in the diagnosis of immediate Blactam allergy. Allergy 2007;62:47-52.

19. De Weck AL, Sanz ML, Gamboa PM, Aberer W, Bienvenu J, Blanca M, et al. Diagnostic Tests Based on Human Basophils: More Potentials and Perspectives than Pitfalls. II. Techincal Issues. J Investig Allergol Clin Immunol 2008; 18(3): 143-155.

20. Torres MJ, Padial A, Mayorga C, Fernandez T, Sanchez-Sabate E, Cornejo-Garcia J, et al. The diagnostic interpretation of basophil activation test in immediate allergic reactions to betalactams. Clin Exp Allergy 2004;34:1768-1775.

21. Sanz ML, Gamboa PM, Antepara I, Uasuf C, Vila L, Garcia-Aviles C, et al. Flow cytometric basophil activation test by detection of CD63 expression in patients with immediate-type reactions to betalactam antibiotics. Clin Exp All 2002;32: 277-286.

22. Ebo DG, Sainte-Laudy J, Bridts CH, Mertens CH, Hagendorens MM, Schuerwegh AJ, et al. Flow-assisted allergy diagnosis: current applications and future perspectives. Allergy 2006: 61: 1028-1039.

23. Abuaf N, Rostane H, Rajoely B, Gaouarw H, Autegardenw JE, Leynadierw F, et al. Comparison of two basophil activation markers CD63 and CD203c in the diagnosis of amoxicillin allergy. Clinical and Experimental Allergy 2008;38: 921-928.

24. Fernandez TD, Torres MJ, Blanca-Lopez N. Negativization rates of $\mathrm{IgE}$ radioimmunoassay and basophil activation test in immediate reactions to penicillins. Allergy 2009;64:242-248

25. Silva R, Cruz L, Bothelo C, Cadinha S, Castro E, Rodrigues J, et al. Work up of patients with history of beta-lactam hypersensitivity. Allergol Immunopathol 2009;37(4):193-197.

26. Romano A, Ventura M. Advances in Diagnosing Drug Hypersensitivity reactions. Current Pharmaceutical Design 2008; 14(27): 2767-2769.

27. Blanca M, Romano A, Torres MJ, Fernandez J, Mayorga C, Rodriguez J, et al. Update on the evaluation of hypersensitivity reactions to betalactams. Allergy 2009; 64:183-193.

28. Brockow K, Garvey L, Aberer W, AtanaskovicMarkovic M, Barbaud A, Bilo M, et al. Skin test concentrations for systemically administered drugs- an ENDA/EAACI Drug Allergy Interest Group position paper. Allergy 2013; 68:702-712. 